\title{
Competition and Risk-Taking in Investment banking
}

\begin{abstract}
How does competition affect the investment banking business and the risks individual institutions are exposed to? Using a large sample of investment banks operating in seven developed economies over 1997-2014, we apply a panel VAR model to examine the relationships between competition and risk without assuming any a priori restrictions. Our main finding is that investment banks' higher risk exposure, measured as a long-term capital-at-risk and return volatility, was facilitated by greater competitive pressures especially for full service investment banks but also for boutique investment banks. Overall, we find some evidence that more competition leads to more fragility before and during the recent financial crisis.
\end{abstract}

JEL classification: D4, G3, G24

Keywords: Investment Banking; Competition; Risk; Panel VAR. 


\section{Introduction}

Until the 2007 global financial crisis, the investment banking business enjoyed a prolonged period of prosperity and stability. Deregulation and technological improvements have contributed to the integration of investment and commercial banking and encouraged greater competitive pressures in the financial services sector (Goddard et al., 2007). As the industry became more contestable, firms were increasingly driven by profit maximizing motives. Many developed as large full-service institutions and responded to the decline in commissions gained from their traditional securities business by seeking new income sources. In particular, product and services diversification has led to greater (and possibly excessive) risk-taking activities and exposure, including proprietary trading and dealing with complex financial securities (Altunbas et al., 2009; Carbó-Valverde et al., 2011 and 2012). This increase in investment banks' risk exposure could have contributed significantly to the greater fragility of the banking and financial sector.

But how do investment banks compete? And how does competition affect the investment banking business and the risks these banks are exposed to? So far, we could not find any answer to these questions in the existing academic literature. Previous studies on this topic mainly focus on the commercial banking industry and largely overlook investment banks, although these latter played a critical role in generating and spreading the global financial crisis. Therefore, shedding lights on the mechanisms through which they can raise their risk-exposure is of great importance to policy-makers to identify prompt and efficient interventions to make the system less fragile.

This paper covers this gap and contributes to the existing literature in several ways. First, we empirically provide new insights on the relationship between competition and risk for a large sample of investments banks, covering a relatively long time span for both the pre- and postcrisis period (1997-2014). Our first contribution is to construct a unique dataset of investment 
banking institutions operating in seven developed economies (i.e. France, Germany, Italy, Japan, Switzerland, UK and the US). Not only our dataset is larger than those analyzed in published studies on investment banks (e.g. Mamatzakis and Bermpei 2014; Radić et al., 2012; and Beccalli, 2004), but it also contains detailed information obtained from several sources: Bankscope, DataStream, the World Bank's World Development Indicators, and the Heritage Foundation.

Second, we measure competition in the investment banking business at the firm level using both the Efficiency-Adjusted Lerner Index of Monopoly Power (Koetter et al., 2012) and the Excess Price-Cost Margin (Gaspar and Massa, 2006). These measures have a number of advantages over traditional competition measures as they enable us to better account for investment banking features and for risk originated from profit maximisation. We also calculate several ad-hoc measures of investment banks' risk-taking that proxy for two measures of volatility of an investment banks' performance (i.e. rolling volatility for both ROA and total revenues), earnings-at-risk exposure and market risk.

Thirdly, we distinguish between boutique investment banks (BIBs) and full service investment banks (FSIBs). The former specialize in particular segments of the market; they do not offer a broad range of services and are not part of larger financial institutions; while the latter offer clients a range of services including underwriting, merger and acquisition advisory services, trading, merchant banking and prime brokerage. ${ }^{1}$ Globalization, through cross border investment flows, and M\&As, as well as direct and portfolio investment in emerging markets have fuelled the profitability particularly of FSIBs while, at the same time, exposing them to foreign market risks. Buch et al. (2013) note that international diversification may reduce but also increase the risk of an international financial firm depending on the correlation between domestic and foreign returns and on the volatility of foreign markets. Therefore, it is important to examine the

\footnotetext{
${ }^{1}$ For more details see e.g. Radić et al., (2012); Davis (2003); Gardener and Molyneux (1995).
} 
relationship between competition and risk by considering the different exposures to international markets of investments banks.

Finally, we formalize the relationship between risk exposure and market conditions in investment banking by implementing a panel-data vector auto-regression (VAR) methodology. This econometric approach fits very well our research aims since it allows us to test the impulse responses of risk exposure to changes in the market structure and competition levels, and vice versa, while considering bank- and industry-specific effects. We test for the short- and long-run effects of a change in risk exposure on the changes in competition and vice versa. As far as we are aware our study is the first to apply a panel VAR approach in assessing the bank competitionrisk taking relationship. We also perform several robustness and sensitivity checks to assess the reliability of our baseline results.

Our evidence shows that higher competition (low market power) measured by the EfficiencyAdjusted Lerner index of Monopoly Power or the Excess Price-Cost Margin is associated with higher risk exposure for both BIBs and FSIBs in terms of increase in earnings-at-risk or revenue volatility. We therefore find some support for the competition-fragility hypothesis in the investment banking industry both before and during the crisis. These results are consistent with several previous studies on commercial banks (e.g. Keeley, 1990, Allen and Gale, 2004; Repullo, 2004; Forssbæck and Shehzad, 2015). However, we also find a positive relationship between market power and market risk. This result is not unusual in the literature since market measures change more frequently than accounting measures and better take into account market perceptions of the bank's soundness in the future (Zigraiova and Havranek, 2016). Finally, compared to the existing research on commercial banks, we show that business models matter for risk-exposure. We find that smaller and more specialised boutique investment banks are less 
likely to be affected by changes in competition, while bigger and full-service banks appear to increase their risk-exposure as competition increases as well.

The remainder of the paper is structured as follows. Section 2 reviews the main literature and sets out the research hypotheses. Section 3 describes the data sources and the empirical framework. Section 4 discusses the results and Section 5 concludes.

\section{Literature review}

Over the 1990s the deregulation process that was carried out in the banking sectors of most developed countries was rooted in the idea that stimulating competition and increasing contestability in banking was the way forward to better quality of provision and sustainable growth (Molyneux et al., 1994). More competition in banking was expected to foster efficiency, stimulate innovation and boost international competitiveness. Various studies (e.g. Claessens and Laeven, 2004), in contrast, notably suggested that the view that competition is unambiguously good is more naïve in banking than in other industries.

The empirical literature on the relationship between bank competition and risk, at least for commercial banks, is generally well established (for comprehensive reviews see Dick and Hannan, 2010; and Casu et al., 2012) and can broadly be related to the investment banking business. The theoretical approaches identify two views: the 'competition-fragility' (Keeley, 1990, Allen and Gale, 2004; Repullo, 2004; Forssbæck and Shehzad, 2015) that argues that competition leads to more fragility and posits that in uncompetitive markets, banks earn monopoly rents resulting in higher profits, capital ratios and charter values. This makes them better placed to withstand demand- or supply-side shocks and discourages excessive risk-taking. Conversely, the 'competition-stability' view (Boyd and De Nicolò, 2005; De Nicolò and 
Lucchetta, 2009), argues against less competition claiming that the considerable market power of only a few banks will cause them to raise the interest rate on loans. This will adversely select the firms with risky projects and produce a negative impact on the stability of the banking system. Yet, there are theories suggesting that this relationship may not be so simple in that higher competition may transform the nature of banking and induce banks to become more or less relationship-oriented (Boot and Thakor, 2010).

Despite the importance of the investment banking industry and the potential costs for society in case of insolvency as shown in the recent global crisis, there are only a handful of studies on the subject. The focus is typically on either the performance of investment banks (Radić, et al., 2012; Mamatzakis and Bermpei, 2014), or relationship-lending in investment banking (Anand and Galetovic, 2006; Boot and Thakor, 2000). While the former stream of literature deals with determinants of profitability in the industry based on their risk levels, the latter focuses on the link between relationship lending and competition. For example, Anand and Galetovic (2006) find evidence that investment banks establish relationships without either local or aggregate monopoly power, but do not assess the reasons behind this. The authors also poise that competition need not 'kill' relationships. Boot and Thakor (2000) predict that capital market competition reduces relationship lending and that this could ultimately affect the nature of the investment banking business.

One of the main limitations of studies assessing the link between relationship lending and competition is that these dealings are considered in-direct (i.e., the sunk costs incurred by investment banks in establishing and maintaining each relationship are large and have already been incurred). Equally, due to better information processing, growth of securitization market, and availability of new rating tools and credit scoring information, a close bank-firm relationship 
gets seemingly less important. Hence, banks will compete and earn higher margins mainly due to their risk exposure. ${ }^{2}$

In this study, we expect that changes in competition will affect the investment banking industry and the risks these banks are exposed to. As far as we are aware, it is the first to explore the intertemporal relationship between investment banking sector competition and risk using panel VAR approach. Our results shed light on the competition-fragility puzzle (i.e. greater industry competition predicts an increase in banks' risks) with specific reference to the investment banking industry.

\section{Data and methodology}

\subsection{Data}

We analyze worldwide professional service firms: investment banks, securities houses, private banking and asset management companies. The data used in the empirical analysis is drawn from various sources: Bankscope, DataStream, the World Development Indicators of the World Bank, and the Heritage Foundation's Index of Economic Freedom database. We apply a number of selection criteria to arrive at our final sample. We consider unconsolidated data and we omit banks for which essential financial information is either not available (i.e., assets, equity, net income, specialization description) and/or is available for fewer than three consecutive years. We also exclude banks where that do not provide the financial information we need to estimate our measures of market power. Lastly, we exclude countries for which we have information on fewer than 50 bank-year observations.

\footnotetext{
${ }^{2}$ As such, the market power proxy, as a measure of competition, should capture incurred costs.
} 
Our final sample comprises 116 investment banks operating in five European countries namely France, Germany, Italy, Switzerland, UK and Japan and the US over 1997-2014. Table 1 reports some key financial indicators including mean profitability, asset size and sector concentration (HHITA). In the US, banks appear to be the largest and the most profitable, while German and Swiss banks are comparatively smaller and less profitable. In terms of asset composition, we observe that US institutions have the largest share of securities holding (about $2 / 3$ of their total assets) compared to the other countries; whereas Italian banks have the largest share of loans ( $45 \%$ of their total assets). The least concentrated markets are those in the US, the UK, and Switzerland, while the most concentrated are found in continental Europe (France, Germany and Italy).

\section{$<<<$ INSERT TABLE $1>>>$}

In order to investigate the specialization effect, we create a cluster sample by investment bank type. As in Radić et al. (2012), we distinguish between boutique investment banks (BIBs) and full service investment banks (FSIBs). The former are typically smaller in size and specialize in particular segments of the market in order to achieve greater profitability and survive competitive pressures from their larger peers in the industry, while full service investment banks strive to control their cost base in order to maximize their shares of revenue globally. To correctly identify these two groups of banks we collected information from three different sources so that to have a comprehensive and accurate profile of each bank. ${ }^{3}$

\footnotetext{
${ }^{3}$ Specifically, first we drew information on bank specialization and main business activity from Bankscope. Second, we obtained financial data by extracting additional specialization information and daily trading prices from Datastream. Third, we cross-checked previous steps with individual bank annual reports and Bloomberg
} 


\subsection{The empirical framework}

\subsubsection{Measuring market conditions}

We use two proxies for measuring investment banking market conditions that capture competition at the bank level. The first is the Efficiency-Adjusted Lerner index of monopoly power (EALER) as proposed by Koetter et al. (2012). Unlike the conventional Lerner Index that has been frequently used to assess competition in the commercial banking sector (see for example, Fernandez de Guevara et al., 2005; Turk-Ariss, 2010; Beck et al., 2013), this adjusted measure of market power enables us to better account for specific features of investment banking activities (i.e. non-lending activities). More specifically, while the conventional Lerner index includes the average risk premium charged by banks to their customers in the price calculation, the Efficiency-Adjusted Lerner index in addition to that accounts for risk originated from profit maximization objective of investment banks. ${ }^{4}$

As in Koetter et al., (2012), the EALER is derived by estimating a translog cost function with three inputs, two outputs and a time trend as follows:

$$
\begin{aligned}
\operatorname{lnTC_{i,t}(\operatorname {ln}TP_{i,t})} & \\
& =\beta_{0}+\sum_{j=1}^{2} \beta_{i} \ln Y_{j i t}+\sum_{k=1}^{3} \alpha_{k} \ln P_{k i t}+\sum_{j=1}^{2}\left(\varphi_{i} / 2\right)\left(\ln Y_{j i t}\right)^{2}+\sum_{k=1}^{3}\left(\zeta_{i} / 2\right)\left(\ln P_{k i t}\right)^{2} \\
& +\sum_{j=1}^{2} \lambda_{i k} \ln Y_{j i t} \sum_{k=1}^{3} \ln P_{k i t}+\sum_{\tau=1}^{2} \xi_{t} T^{\tau}+\sum_{k=1}^{3} \omega_{k} T \ln P_{k i t}+\sum_{j=1}^{2} \rho_{i} T \ln Y_{j i t}+\varepsilon_{j t}
\end{aligned}
$$

Businessweek classification information. Finally, we dropped all cases of inconsistent or missing data and where banks were identified as trading or asset management companies only.

${ }^{4}$ Koetter et al. (2012) demonstrates that the Lerner index is biased when profit inefficiencies are ignored, based on a study focusing on the US banking industry. 
where TC denotes total cost, TP denotes profit before tax; $P_{k \mathrm{jt}}$ input factors to the production process of investment banks $i=1,2, . ., \mathrm{n}$ at time $t$, respectively $P_{1}$, the price of labour, calculated as personnel expenses over total assets, $P_{2}$, the price of physical capital, measured as other administrative expenses plus other operating expenses over total fixed assets; and $P_{3}$, the price of other interest bearing liabilities and deposits short term funding; on the output side, we follow Radić et al. (2012) and consider investment banks' business as follows: total earning assets ( $\left.\mathrm{Y}_{1}\right)$, that is the sum of loans and other earning assets of bank $i$ in year $t$, and investment banking fees $\left(\mathrm{Y}_{2}\right)$, calculated as the sum of commission, fee and trading income of bank $i$ in year $t$; and $T$ is a time trend to capture technical change. We assume that $\varepsilon_{j}=v_{j}+u_{j}$, where random error $v_{j}$ is assumed to be i.i.d $\mathrm{N}\left(0, \sigma_{V}^{2}\right)$ and independent of $u_{j}$. The terms $u_{j}$ are non-negative random variables which are assumed to account for cost inefficiency and to be i.i.d. as truncations at zero of the $\mathrm{N}\left(0, \sigma_{U}^{2}\right)$. We specifically employ the time-varying stochastic frontier model for panel data for both the cost and profit functions.

From equation (1), the marginal costs can be derived by taking the sum of the derivatives with respect to total earning assets $\left(\mathrm{Y}_{1 i t}\right)$ and investment banking fees $\left(\mathrm{Y}_{2 i t}\right)$ which yields:

$$
\begin{aligned}
M C_{i, t}=\frac{T C_{i t}}{Y_{1 i t}}\left[\beta_{1}+\varphi_{1} \ln Y_{1 i t}+\left(\frac{\varphi_{i_{1}}}{2}\right) \ln Y_{2 i t}+\sum_{K=1}^{3} \lambda_{1 k} \ln P_{k i t}+\omega_{1} T\right] \\
+\frac{T C_{i t}}{Y_{2 i t}}\left[\beta_{2}+\varphi_{2} \ln Y_{2 i t}+\left(\frac{\varphi_{i 2}}{2}\right) \ln Y_{1 i t}+\sum_{K=1}^{3} \lambda_{2 k} \ln P_{k i t}+\omega_{2} T\right]
\end{aligned}
$$

The EALER is dependent on the "price" set by the bank and the marginal cost of producing one additional "unit". While in commercial banking industry the price is proxied by total revenue over assets, and marginal costs is estimated for an additional unit of assets based on total personnel and other costs, this is less so in the case of the investment banking industry. 
Investment banks can perform several advisory services without requiring a large asset basis; and there are also substantial economies of scale in the industry (e.g. market making activities in securities and derivatives markets, etc.) with some business lines that have large fixed costs. Potentially, only investment banks' activities for which revenue over assets is an adequate price measure would seem to be the underwriting of private placements or syndicated loans. Therefore, in order to estimate the price $p$ in the Lerner Index for the investment banking industry, we conjecture that forgone profits due to sub-optimal production levels are substantially larger compared to potential cost inefficiencies, so we also consider profit inefficiencies in the measurement of average revenues. ${ }^{5}$

Using predicted total costs (PTC), corresponding marginal costs (MC), and predicted profits (PTP) relative to total output $(\mathrm{TO}=$ total earning assets + investment banking fees $)$, an Efficiency-Adjusted Lerner index can be calculated as follows:

$E A L E R=\frac{\frac{P T P}{T O}+\frac{P T C}{T O}-M C}{\frac{P T P}{T O}+\frac{P T C}{T O}}=\frac{P T P+P T C-M C x T O}{P T P+P T C}$

EALER is thus derived from frontier estimates of PTP, PTC, and MC. Higher EALER (higher market power) is interpreted as lower competition.

Our second proxy for market power at the bank level is Excess Price-Cost Margin (EPCM), defined as the difference between a bank's operating profit margin (PCM) and the average operating profit margin of its industry. We follow Gaspar and Massa (2006) and their implementation of the price-cost margin (as equal to operating profits over revenues) and assumption, that average variable cost is a meaningful proxy for marginal cost. We then calculate

\footnotetext{
${ }^{5}$ This assumption is also in line with bank efficiency studies (for more info, please see Berger and Humphrey, 1997; Koetter et al., 2012).
} 
the logarithm value of this difference after having rescaled it by subtracting the minimum value at the bank level. Higher EPCM is associated with lower competition. Our second proxy, EPCM variable is better able to capture intra-industry differences in pricing power, that are due to the fact that different industries might have structurally different rates of profit for reasons unrelated to market power. ${ }^{6}$

\subsubsection{Measuring risk}

We measure investment banks' risk-taking by using a detailed set of tailored measures that proxy for overall risk exposure: earnings-at-risk; a measure of rolling standard deviation of ROA over 3 years; a measure of rolling standard deviation of logarithm of total revenues over 3 years; and market risk.

Firstly, we further advance the existing literature (see for example Davis, 2003) by employing a measure of earnings-at-risk exposure. In particular, we measure the investment banks' Capital-AtRisk (CAR) using the alternative Earnings-at- Risk (EAR) estimation. Specifically, CAR can be defined as the amount of risk capital that a firm requires to cover the risks that it is running or collecting as a going concern. In order to do so we employ EAR that is a standard risk management technique (Andrén et al., 2005; Stein et al., 2001) which allows us to estimate the worst variation in earnings of the company, for a fixed time horizon and with a pre-established confidence level. Specifically, the EAR is obtained using a parametric model as follows:

$E A R=\eta+z_{(1-\alpha) / 2} \sigma$

\footnotetext{
${ }^{6}$ The criticisms made to the price-cost margin is that it does not take into account the cost of capital and that is usually valid only for companies that operate in a single line of business. In our sample the majority of banks are smaller and specialized, so adding another proxy for market power that is able to better capture these bank types seems justifiable (Gaspar and Massa, 2006).
} 
where $\eta$ is the investment banks' profit before tax (PBT); $\sigma$ is the standard deviation of PBT over the sample period; and $z_{(1-\alpha) / 2)}$ is the probability associated with the $\alpha$ confidence level estimated assuming a normal distribution of earnings. In particular, if we assume that the earnings decline is permanent (long-term), consequently, the investment bank needs to hold an equity level equal to the present value of perpetuity of EAR as follows:

$$
C A R=\frac{E A R}{\text { roe }}
$$

where, roe is the mean bank Return On Equity estimated over the sample period. It is evident that higher measures of $C A R$ correspond to higher risk for the banks.

Secondly, we follow Beck et al. (2013) and make our next dependent variable directly proportional to banking stability. In particular, we calculate the rolling volatility for both ROA and total revenues over a period of three years. This is a measure of the volatility of an investment bank's performance. A higher volatility can exert a negative effect on a bank's viability and growth opportunities.

Finally, we use a market risk measure (MR), which captures the standard deviation of stock returns at the bank level. This risk proxy only accounts for listed banks and takes in account the idiosyncratic volatility of the stock of investment banks as suggested by Deng and Elysiani (2008). To recap, an increase in CAR, olnTR, $\sigma \mathrm{ROA}$ and MR means more risk-exposure for an investment bank.

The correlation coefficients between the risk measures are usually positive and significant at one percent, while the correlation between EALER and EPCM is also positive, albeit insignificant.

$\leq<<$ INSERT TABLE $2>>>$ 


\subsubsection{The relationships between risk and competition: a panel VAR approach}

To formalize the relationship between risk exposure and market conditions in investment banking industry, we rely on panel-data vector autoregression methodology (PVAR). This econometric approach fits very well our research aims since it allows us to test the impulse responses of risk exposure to changes in competition levels, and vice versa, while taking into account bank and country-specific effects. This methodology enables us to avoid imposing a priori assumptions about the relationship between risk and competition variables in the model. As such, we follow Love and Zicchino (2006), and Abrigo and Love (2016) and specify our model as follows ${ }^{7}$ :

$Y_{i t}=Y_{i t-1} A_{1}+X_{i t} B+u_{i}+e_{i t}$

where, $\mathrm{Y}_{(\mathrm{t})}$ is a two-variable vector of endogenous variables that consist of risk and competition, $X_{i t}$ is a $(1 x l)$ vector of exogenous covariates; $u_{i}$ and $e_{i t}$ are (1xk) vectors of dependent variablespecific panel fixed-effects and idiosyncratic errors. Therefore, risk and competition variables enter the model as endogenous variables. In this way we are able to deal with endogeneity concerns due to reverse causality. Previous recent papers (e.g. Beck et al., 2013) employed IV (2SLS) estimator and two-step generalized method of moments (GMM) estimator to address endogeneity issue, or Granger causality to examine competition-stability nexus (e.g. Fiordelisi and Mare, 2014). In our study, we not only take into account endogeneity issues, but we also explore the short and long-run effects of a change in risk (competition) for the effect of a change in competition (risk).

\footnotetext{
${ }^{7}$ For recent applications of Love and Zicchino (2006)'s model to the banking sector see e.g. Delis et al., (2014), Head et al., (2014); Imbierowicz and Rauch (2014).
} 
As suggested by Love and Zicchino (2006), the original variables are time-demeaned and the fixed individual effects are removed by the Helmert transformation method. To set the number of lags we employ the Andrews and Lu (2001)'s procedure for GMM models based on Hansen's (1982) J statistic of over-identifying restrictions. The test suggests 1 lag ( $\mathrm{q}=1$ ) is optimal. To control for bank-specific effects we use mean differencing - the so-called Helmert's transformation - which allows for transformed variables and orthogonal lagged regressors. In this way, we can use lagged regressors as instruments and use GMM to estimate the PVAR. We employ 1000 Monte Carlo simulations to get bootstrapped confidence intervals for the impulse response functions. We also subtract from each variable in the model its cross-sectional mean before estimation to remove time fixed effects. This should help mitigate endogeneity concerns generated by omitted variables.

Finally, we compute forecast-error variance decomposition (FEVD) based on a Cholesky decomposition of the residual covariance matrix of the underlying panel VAR model and again using 1000 Monte Carlo simulation. In accordance with Abrigo and Love (2016) we drop the exogenous variables when calculating the FEDV. This decomposition allows us to observe the magnitude of the total effect because it shows the percentage of variation in one variable explained by the 'shock' (i.e. a change) to another variable over time.

Equation (6) shows that we incorporate in the model a $X_{i t}$ set of variables that describe different bank-specific and macro factors that we believe should be controlled for when investigating the relationships between risk and competition in the investment banking industry. As discussed above, we control for bank type by splitting the sample into boutique and full investment banks. We also recognize the possibility that regulation, supervision and other related factors that restrict banks' activities may have a significant impact on competition and market structure. Therefore, we 
include an Index of Economic Freedom that provides us with a portrait of a country's economic policies over time $(E C F)$. We also control for business cycle effects by adding the annual real GDP growth $(\triangle G D P)$ to the model. This macroeconomic variable is commonly used in the banking literature (e.g. Salas and Saurina, 2003; Yildirim and Philippatos, 2007; Brissimis et al., 2008) and is expected to influence the relationship among risk-capital-efficiency-competition. A summary of the variables used for the empirical investigation is provided in Table 3, including the descriptive statistics for the main variables of interest for the aggregate sample over the observed time period.

\section{Discussion of results}

\subsection{Analysis of PVAR}

We run a panel vector autoregressive (PVAR) model to explore the effect of the risk exposure shocks on bank competition and vice versa. We first estimate the coefficients of the PVAR system given in equation (6) after country-time and bank-specific fixed effects have been removed. Table 4 and Table 5 report the results of the main model with the Efficiency-Adjusted Lerner Index (EALER) and the model with Excess Price-Cost Margin (EPCM), respectively. Results include the full sample of banks in each country. 
Table 4 shows that EALER at time $t$-1 predicts CAR, olnTR and $\sigma$ ROA (columns 1 and 3). We find evidence that competition exhibits a negative impact on CAR and $\sigma \ln T R{ }^{8}$ These findings suggest that higher competition (lower market power) can increase investment banks' risk exposure in terms of earnings-at-risk or revenue volatility. The estimated coefficient for $\sigma \mathrm{ROA}$ is positive and statistically significant at five percent confidence level. Interestingly, EALER impacts positively on $\sigma \mathrm{ROA}$ only in the short-term; it then exhibits a reverse trend as further tested in Section 4.2. In contrast, competition is statistically insignificant when we use market risk as dependent variable.

\section{$\leq<<$ INSERT TABLE $5>>>$}

Results reported in Table 5 show that the response in risk exposure to increase in EPCM is significant and negative in the case of CAR and olnTR. Additionally, an increase in EPCM appears to be positively and significantly related to MR. This result is not unusual in the literature since market measures change more frequently than accounting measures and better take into account market perceptions of a bank's soundness in the future (Zigraiova and Havranek, 2016). As in the case of EALER we find that an increase in competition is followed by increase in earnings-at-risk and revenue volatility. Consistently with the arguments of Hellman et al., (2000) and Allen and Gale (2004), our results for CAR and olnTR imply that banks in competitive markets (and lower market power) increase their risk profile.

Focusing on the institutional environment in Table 4, a higher ECF appears to be associated with an increase in risk exposure and competition only for $\sigma \mathrm{ROA}$ (at the 1 per cent confidence

\footnotetext{
${ }^{8}$ The Hansen's (1982) test always rejects the hypothesis of over-identifying restrictions and therefore confirms the validity of our instruments.
} 
level). In the case of EPCM model (Table 5) we find no such effect. GDP growth does not appear strongly linked to investment banks' risk (with the exception of CAR), however we find that GDP growth at time $t-1$ is negatively and significantly related to both EALER and EPCM.

\subsection{Impulse responses}

We also examine the orthogonalized impulse-responses of the banks' risk measures to competition shock. Figure 1 reports the effect on a change $(\Delta)$ in risk measures of shock to EALER, while Figure 2 focuses on the effect on $\Delta$ in risk measures of shock to EPCM. The responses of the variables are depicted by the solid lines, while the grey area refers to the $95 \%$ confidence interval. The simulation horizon covers three periods. Before running the impulseresponses function we verify that PVAR satisfies the stability conditions.

\section{$\leq<<$ INSERT FIGURE $1>>>$}

After running the full sample analysis, we notice that for some risk measures, the confidence interval for the impulse-response function is large. ${ }^{9}$ This suggests that after transforming the data there is still heterogeneity in the response function to a shock of either EALER or EPCM. So, we identify the business model of investment banks as a possible source of heterogeneity in our sample. As discussed in Section 3.1, boutique and full service investment banks differ because of their business specialization. Boutique banks mainly deal with specific lines of activities and geographical regions, while full service investment banks are more diversified both in terms of products and services offered and covered geographical area. As boutique investment banks

\footnotetext{
${ }^{9}$ These results are available upon the request from the authors.
} 
operate in niche markets, they tend to be less exposed to a shock in competition, but they tend to be more vulnerable to macro-economic or demand shocks as they are less diversified. Therefore, we could expect full service investment banks to react differently to a shock in competition compared to boutique banks. Consequently, we run the PVAR analysis by splitting the sample for boutique banks and full-service investment banks only. Specifically, Figure 1 reports the orthogonalized impulse-response function for risk measures to shock to EALER for both groups of banks.

Figure 1 illustrates significant and negative impulse response functions of CAR and $\sigma \operatorname{lnTR}$ (FSIBs and BIBs) and MR (FSIBs) for the effect of a shock to EALER. Instead, the impulse response function of $\sigma \mathrm{ROA}(\mathrm{BIBs})$ is positively and significantly related to a shock to EALER only in 1-year horizon. In contrast, the impulse response functions $\sigma$ ROA (FSIBs) and MR (BIBs) to a shock to EALER are never significantly different from zero.

Figure 2 displays the impulse-response functions for risk measures to shock to EPCM for both boutique and full-service investment banks.

\section{$\leq<<$ INSERT FIGURE $2>>>$}

By focusing only on changes to risk measures for the effect of EPCM, we notice that boutique and full service investment banks react almost in the same way to a shock to EPCM. Especially in the case of CAR, both boutique and full-service investment banks are negatively and significantly related to a shock to EPCM. In fact, the reaction is almost identical. Equally, the impact on $\sigma \operatorname{lnTR}(\mathrm{FSIBs})$ is also significant and negative. $\sigma \operatorname{lnTR}$ (BIBs) and MR appear to not react significantly to a shock to EPCM, as the effect of shock to EPCM seems to wear off relatively quickly. Boutique investment banks tend to exhibit a reverse trend after 1-year horizon. 
$\sigma R O A$ follows similar pattern but the positive magnitude of the shock in the case of boutique investment banks is even greater, then again wears off in period 3. Overall, for the above variables we seem to find evidence of only a significant short effect.

Differently from EALER in Figure 2, we find that the confidence intervals are smaller. This indicates that there may be less heterogeneity left in the response functions between risk measures and EPCM.

Overall, by splitting the sample based on banks' specialization we observe some interesting patterns. Smaller and more specialised boutique investment banks are less negatively affected by changes in competition than bigger and full-service banks. This is plausible since the former are likely to be affected by higher volatility of earnings in the short-run while it is plausible to contend that full service banks, due to their more diversified income streams, are more likely to get affected in the long run if there are changes to their viability and growth opportunities.

\subsection{Risk and competition before the outbreak of the global financial crisis}

The global financial crisis and the more recent eurozone sovereign debt crisis, have had a profound impact on the stability of the financial system, its ability to smooth flow of funds and help promote growth in economic activity. It is well known that several large banking institutions failed and exited the market (e.g. Lehman Brothers), while others were either taken over or nationalised (i.e. Merrill Lynch, Royal Bank of Scotland). Public authorities have adopted wideranging interventions (i.e. recapitalization, debt guarantees, asset purchases) to help reduce the fragility of the banking system and restore confidence in the markets. However, it is reasonable to expect that the crisis could have altered both the overall risk exposure and the competitive 
dynamics in the banking sector (e.g. Berger and Bouwman, 2013; Calderon and Schaeck, 2015). Given the above, we rerun our analysis by solely focusing on the years before the financial crisis.

Table 6 reports the main results. It appears that even in the period prior to the crisis, EALER affects negatively CAR and positively $\sigma$ ROA. Similarly to our main results, we also find evidence of reverse causality for CAR. When significant, ECF and GDP at time $t-1$ are still negatively related to EALER.

\section{$<<$ INSERT TABLE $6>>>$}

Finally, Table 7 shows that EPCM is again negatively related to CAR and to $\sigma \operatorname{lnTR}$. However, EPCM does not appear to enhance market risk volatility of investments banks anymore. Overall, and apart from $\sigma \mathrm{ROA}$, our result support our main conclusion from Section 4.1 where we find that more competition leads to more fragility for the investment banking sector, both in crisis and non-crisis years.

\section{$\leq<<$ INSERT TABLE $7>>>$}

\subsection{Variance decomposition}

Table 8 reports the forecast error variance decomposition (FEVD) at the 1- to 3-year forecast horizon. In particular, part 8a illustrates the FEVD for EALER or EPCM (the risk measures are the impulse variables) while part $8 \mathrm{~b}$ shows the FEVD of each risk measure (EALER and EPCM are the impulse variables). We compute FEVD based on the Cholesky decomposition of the residual covariance matrix for each specification of our Panel VAR model. We also run 1000 
Monte Carlo draws to estimate the standard errors and confidence intervals. We finally exclude the exogenous variables from the baseline PVAR model to get reliable FEVD (Abrigo and Love, 2005). Differently from the impulse-response function, the FEVD allows us to get more insights on the magnitude of each shocks exerted by a change on the competition measures. This is important to grasp the economic meaning of changes in risk measures because of shock to competition measures.

\section{$\leq<<$ INSERT TABLE $8>>>$}

Table 8 (part 8a) illustrates that shock to CAR accounts for large variations in EALER with an average effect of $13 \%$ over the forecast horizon. Further, with a variation of about $5 \%$ and $2 \%$, the contribution of respectively olnTR and $\sigma \mathrm{ROA}$ shock to fluctuations of EALER is also sizeable. We find similar figures in the case of EPCM. More specifically, $\sigma \ln T R, \sigma R O A$ and this time also MR provide the largest contribution in EPCM's variation. In particular, these risk measures account even up to $34 \%$ in the case of $\sigma \mathrm{ROA}, 12 \%$ in the case of $\sigma \ln \mathrm{TR}$ and $10 \%$ in the case of MR. These findings are in line with our results from Tables 4-7.

Focusing on Table 8 (part 8b) we observe that a shock to EALER only covers a minor part of fluctuations in risk measures. It only explains a variation of $1-4 \%$ of risk measures starting from year 2 (namely for CAR and $\sigma$ ROA). Similarly, a shock to EPCM seems to explain a small portion of the variation of only $\sigma \mathrm{ROA}$ (one per cent). These findings suggest that a shock to competition does not have a direct impact on contemporaneous risk measures. 


\subsection{Robustness Check}

The main results reported in Table 4 are robust to several sensitivity checks. First, we re-run the cost and profit functions by using the Fourier Flexible functional form. Following Bolt and Humphrey (2015) we add the sin and $\cos$ terms to add flexibility to the U-shaped translog specified in equation (1). The results derived from the Fourier specification are reported in Table 9 and they are broadly consistent with those in Table 4, as EALER impacts negatively and significantly CAR and $\sigma \operatorname{lnTR}$, while it has a positive and significant impact on $\sigma \mathrm{ROA}$.

\section{$\leq<<$ INSERT TABLE $9>>>$}

Second, we employ as robustness check the Boone indicator (Boone, 2008), that is a relatively new measure of competition that is essentially a profit elasticity and focuses the strength of the relationship between efficiency (measured in terms of marginal costs) and performance (profitability). Following e.g. Liu et al., (2013) and Schaeck and Cihak (2014), we calculate the elasticity of profits $(\pi)$ to marginal costs by country and year as shown in equation (7).

$$
\ln \pi_{i t}=\alpha+\beta \operatorname{lnm} c_{i t}+e_{i t}
$$

where the marginal cost $(m c)$ is calculated using a translog cost function (see Equation 2). The Boone is negative because profits and marginal cost exhibit a negative relationship; a larger Boone indicator in absolute value indicates a more competitive banking industry.

Results are reported in Table 10 and are consistent with the results reported in Table 4 in only two cases (CAR and $\sigma$ ROA). Although the Boone indicator has many appealing qualities it often underperforms in comparative tests of banking market conditions hence results should be treated 
with some caution (Liu et al., 2013; Schiersch and Schmidt-Ehmcke, 2010). One possible reason is that the Boone makes critical assumptions relative to firm size and to market definition. In addition, it does not offer a measure of market power at the bank-year level (for more details see e.g. Delis et al., 2016).

\section{$\leq<<$ INSERT TABLE $10>>>$}

Finally, following Delis et al., (2016), we test for potential non-linear effects between competition, EALER, and risk. We did not find any evidence of such a linear effect. ${ }^{10}$

\section{Conclusions}

Competition is usually regarded an indispensable force in the economy because it triggers greater efficiency, innovation, enhanced consumers' choices and generally promotes a better allocation of resources. In banking, though, the issue of benefits derived from competition has always been controversial as these should be weighed against the danger of financial instability. Post crisis many viewed competition as a factor leading to higher bank risk-taking.

In this paper, we empirically formalize the relationship between risk exposure and market conditions in the investment banking industry. We employ a panel VAR approach that allows us to capture the impulse responses of risk exposure to changes in competition levels, and vice versa. We use a large dataset of banks from the seven most developed investment banking industries (France, Germany, Italy, Japan, Switzerland, the UK and the US) over 1997-2014 and test alternative measures of market power (as lack of competition) and risk.

\footnotetext{
${ }^{10}$ We thank an anonymous referee for suggesting these tests. Results are available from the authors upon request.
} 
We show that investment banks' response in risk exposure to a competition change is significant and negative as evidenced in the estimated coefficients and impulse responses. We also find that excess price-cost margin raises uncertainty about the banks' market returns. Further, when we check for impulse responses and cluster our sample by business models we find that both boutique investment banks and full-service investment banks exhibit significant changes to earnings-at-risk and revenue volatility due to shock to competition (for both EALER and EPCM), whereas other risk proxies either exhibit no change or the change wears off quickly.

Our results provide some evidence to support the 'competition-fragility view' which argues that competition induces excessive risk-taking and therefore is detrimental for stability because it could result in a higher likelihood of individual banks' failures. These can be very costly for society as witnessed by the events that followed the outbreak of the global financial crisis a decade ago. Our findings appear to hold both prior to the crisis and for the whole period under study, and by investment banks' specialization,BIBs vs FIBS, with a stronger effect for the latter ones. These findings raise at least two implications for policy-makers. On the one hand, the need to better balance policy prescriptions so that to allow a healthy degree of rivalry necessary for ensuring dynamic efficiency of the industry. On the other hand, the findings of this study provide support that a certain level of market power maybe necessary in the investment banking industry to give institutions less incentives to undertake risky business. 


\section{References}

Abrigo, M.R.M., Love, I., (2016). Estimation of Panel Vector Autoregression in Stata: a Package of Programs. http://www.economics.hawaii.edu/research/workingpapers/WP_16-02.pdf

Anand, B., Galetovic, A., (2006). Relationships, competition and the structure of investment banking markets. Journal of Industrial Economics, Vol. 54, Issue 2, 151-199.

Allen, F., Gale, D., (2004). Competition and Financial Stability. Journal of Money, Credit, and Banking, Vol. 36, No. 3, 453-480.

Altunbas, Y., Gambacorta, L., Marques-Ibanez, D., (2009). Securitization and the bank lending channel. European Economic Review, 53, 996-1009.

Andrén, N., Jankensgard, H., Oxelheim, L., (2005). Exposure-based cash-flow-at- risk: An alternative to value-at-risk for industrial companies. Journal of Applied Corporate Finance, 17(3): 76-87.

Andrews, D.W.K., Lu, B., (2001). Consistent model and moment selection procedures for GMM estimation with application to dynamic panel data models. Journal of Econometrics, 101(1), 123164.

Beccalli, E., (2004). Cross-Country Comparisons of Efficiency: Evidence from the UK and Italian Investment Firms. Journal of Banking and Finance, 28, 1363-1383.

Beck, T., De Jonghe, O., Schepens, G., (2013). Bank competition and stability: cross-country heterogeneity. Journal of Financial Intermediation, 22, 218-244.

Berger, A. N., Bouwman, C.H.S., (2013). How does capital affect bank performance during financial crises? Journal of Financial Economics, 109(1), 146-176.

Berger, A.N., Humphrey, D.B., (1997). Efficiency of Financial Institutions: International Survey and Directions for Future Research. European Journal of Operational Research, 98, 175-212.

Boot, A., Thakor, A., (2000). Can Relationship Banking Survive Competition? The Journal of Finance, 55 (2), 679-713.

Boyd, J.H., De Nicolò, G., (2005). The Theory of Bank Risk Taking and Competition Revisited. The Journal of Finance, 60 (3), 1329-1343.

Brissimis, S.N., Delis, M.D., Papanikolaou, N.I., (2008). Exploring the Nexus between Banking Sector Reform and Performance: Evidence from Newly Acceded EU Countries. Journal of Banking and Finance, 32, 2674-2683.

Boone, J., (2008). A New Way to Measure Competition. Economic Journal, 118, 1245-1261.

Bolt, W., Humphrey, D., (2015). A frontier measure of U.S. banking competition. European Journal of Operational Research, 246, 450-461.

Boone, J., (2008). A New Way to Measure Competition. Economic Journal, 118, 1245-1261.

Buch, C., Koch, C., Koetter, M., (2013). Do Banks Benefit from Internationalization? Revisiting the Market Power-Risk Nexus. Review of Finance, Vol. 17(4), 1401-1435.

Calderon, C., Schaeck, K., (2015). The effects of government interventions in the financial sector on banking competition and the evolution of zombie banks. Journal of Financial and Quantitative Analysis (Forthcoming). 
Carbó-Valverde, S., Hannan, H.T., Rodriguez-Fernandez, F., (2011). Exploiting old customers and attracting new ones: The case of bank deposit pricing. European Economic Review, 55, 903915.

Carbó-Valverde, S., Marques-Ibanez, D., Rodríguez-Fernández, F., (2012). Securitization, risktransferring and financial instability: The case of Spain. Journal of International Money and Finance, 31, 80-101.

Casu, B., Girardone, C., Molyneux, P., (2012). Is There a Conflict Between Competition and Financial Stability? In: Barth, J.R., Lin, C., Wihlborg, C., (Eds.), Research Handbook on International Banking and Governance, part 1. Edward Elgar Publishing (Forthcoming).

Claessens, S., Laeven, L., (2004). What Drives Bank Competition? Some International Evidence. Journal of Money, Credit, and Banking, Vol. 36, No. 3, 563-584.

Davis, S.I., (2003). Investment banking: Addressing the management issues. Palgrave MacMillan

Delis, M., Hasan, I., Kazakis, P. (2014). Bank regulations and income inequality: Empirical evidence. Review of Finance, 18: 1811-1846.

Delis, M., Kokas, S., Ongena, S., (2016). Foreign bank ownership and competition: Evidence from a world sample. Journal of Money, Credit and Banking, 48, 449-483.

De Nicolò, G., Lucchetta, M., (2009). Financial Intermediation, Competition, and Risk: A General Equilibrium Exposition. International Monetary Fund, Working Paper 09/105. https://www.imf.org/external/pubs/ft/wp/2009/wp09105.pdf

Deng, S.E., Elyasiani, E., (2008). Geographic diversification, bank holding company value, and risk. Journal of Money, Credit and Banking, Vol. 40, No. 6, 1217- 1238.

Dick, A.A., Hannan, T.H., (2010). Competition and Antitrust Policy in Banking. In: Berger, A.N., Molyneux, P., Wilson, J.O.S., (Eds.), The Oxford Handbook of Banking. Oxford University Press, pp. 405-429.

Fernandez de Guevara, J., Maudos, J., Perez, F., (2005). Market Power in European Banking Sector. Journal of Financial Services Research, 27:2, 109-137.

Fiordelisi F., Mare, D. S., (2014). Competition and financial stability in European cooperative banks. Journal of International Money and Finance, 45, 1-16.

Forssbæck, J., Shehzad, C.T., (2015). The Conditional Effects of Market Power on Bank Risk Cross - Country Evidence. Review of Finance, 10(5): 1997-2038.

Gaspar, J.M., Massa, M., (2006). Idiosyncratic Volatility and Product Market Competition. The Journal of Business, Vol. 79, No. 6, 3125-3152.

Gardener, E., Molyneux, P., (1995). Investment banking: theory and practice. Euromoney Books, London.

Goddard, J., Molyneux, P., Wilson, J.O.S., Tavakoli, M., (2007). European banking: An overview. Journal of Banking and Finance, 31, 1911-1935.

Hansen, L.P., (1982). Large sample properties of Generalized Method of Moments estimators. Econometrica, 50, 1029-1054.

Head, A., Lloyd-Ellis, H., Sun, S., (2014). Search, Liquidity, and the Dynamics of House Prices and Construction. American Economic Review, 104(4): 1172-1210. 
Hellman, T., Mudock, K., Stiglitz, J.E., (2000). Liberalization, moral hazard in banking and prudential regulation: Are capital controls enough? American Economic Review 90 (1): 147-165.

Imbierowicz, B., Rauch, C., (2014). The relationship between liquidity risk and credit risk in banks. Journal of Banking and Finance, 40, 242-256.

Keeley, M.C., (1990). Deposit insurance, risk, and market power in banking. The American Economic Review, 1183-1200.

Koetter, M., Kolari, J.W., Spierdijk, L., (2012). Enjoying the quiet life under deregulation? Evidence from adjusted Lerner indices for US banks. Review of Economics and Statistics, 94, 462-480.

Liu, H., Molyneux, P., Wilson J.O.S., (2013). "Competition in banking: measurement and interpretation", Chapter 8 In: Bell, A.R., Brooks, C., Prokopczuk, M., (eds.) Handbook of Research Methods and Applications in Empirical Finance. Edward Elgar, pp. 197-215.

Love, I., Zicchino, L., (2006). Financial development and dynamic investment behavior: Evidence from panel VAR. The Quarterly Review of Economics and Finance, 46(2), 190-210.

Mamatzakis, E., Bermpei, T., (2014). What drives investment bank performance? The role of risk, liquidity and fees prior to and during the crisis. International Review of Financial Analysis, 35, 102-117.

Molyneux, P., Lloyd-Williams, D.M., Thornton, J., (1994). Competitive conditions in European banking. Journal of Banking and Finance, 18, 445-459.

Pástor, L., Veronesi, P., (2003). Stock Valuation and Learning about Profitability. The Journal of Finance, Volume 58, Issue 5, 1749-1789.

Radić, N., Fiordelisi, F., Girardone, C., (2012). Efficiency and Risk-taking in pre-crisis Investment Banks. Journal of Financial Services Research, 41:81-101.

Repullo, R. (2004) Capital requirements, market power, and risk-taking in banking. Journal of Financial Intermediation, 13, 156-182.

Salas, V., Saurina, J., (2003). Deregulation, Market Power and Risk Behaviour in Spanish Banks. European Economic Review, 47, 1061-1075.

Schaeck, K., Cihak, M. (2014). Competition, efficiency, and stability in banking. Financial Management, 43, 215-241.

Schiersch, A., Schmidt-Ehmcke, L., (2010). Empiricism Meets Theory: Is the Boone-Indicator Applicable?" DIW Berlin, Discussion Paper 1030.

http://www.diw.de/documents/publikationen/73/diw_01.c.358332.de/dp1030.pdf

Stein, J.C., Usher, S.E., LaGattuta, D., Youngen, J., (2001). A comparables approach to measuring cashflow-at-risk for non-financial firms. Journal of Applied Corporate Finance, 13(4): 100-109.

Turk-Ariss, R., (2010). On the implications of market power in banking: Evidence from developing countries. Journal of Banking and Finance, 34, 765-775.

Yildirim, H.S., Philippatos, G.C., (2007). Restructuring, Consolidation and Competition in Latin American Banking Markets. Journal of Banking and Finance, 31, 629-639.

Zigraiova, D., Havranek, T., (2016). Bank competition and financial stability: much ado about nothing? Journal of Economic Surveys, 30(5), 944-981. 
Table 1. Key indicators of the investment banking sectors 1997-2014 (mean values)

\begin{tabular}{|c|c|c|c|c|c|c|c|c|c|}
\hline Country & Pre-TaxProfit* & Assets* & Loans* & Securities* & IB Fees* & Equity* & ROA & ROE & HHITA \\
\hline France & 65,009 & $18,832,577$ & $1,457,758$ & $7,296,549$ & 147,098 & 422,122 & $1.74 \%$ & $13.71 \%$ & 0.396 \\
\hline Germany & 7,384 & $4,989,801$ & $1,320,666$ & $2,212,820$ & 71,574 & 200,237 & $1.18 \%$ & $7.11 \%$ & 0.272 \\
\hline Italy & 102,566 & $19,423,644$ & $6,372,307$ & $8,639,485$ & 80,349 & $1,066,545$ & $1.03 \%$ & $4.87 \%$ & 0.394 \\
\hline Japan & 182,206 & $35,239,665$ & $9,722,419$ & $23,207,237$ & 444,212 & $1,846,815$ & $0.91 \%$ & $5.38 \%$ & 0.237 \\
\hline Switzerland & 38,618 & $4,718,450$ & $1,321,297$ & 937,000 & 101,394 & 387,271 & $1.58 \%$ & $8.17 \%$ & 0.190 \\
\hline UK & 92,632 & $55,732,372$ & $8,596,902$ & $41,049,017$ & 187,072 & $1,599,268$ & $1.02 \%$ & $5.50 \%$ & 0.186 \\
\hline US & 684,678 & $103,528,516$ & $8,994,366$ & $73,030,457$ & $1,915,743$ & $4,928,760$ & $0.51 \%$ & $6.35 \%$ & 0.223 \\
\hline
\end{tabular}

Note: * Data is in USD thousand. 
Table 2. Correlation Matrix

\begin{tabular}{|c|c|c|c|c|c|c|c|c|}
\hline & CAR & $\sigma \ln T R$ & $\sigma \mathrm{ROA}$ & MR & EALER & EPCM & ECF & GDP \\
\hline CAR & 1 & & & & & & & \\
\hline$\sigma \ln T R$ & $0.1982 *$ & 1 & & & & & & \\
\hline$\sigma \mathrm{ROA}$ & 0.0006 & $0.2648 *$ & 1 & & & & & \\
\hline MR & $0.2661 *$ & $0.3626^{*}$ & $0.1561 *$ & 1 & & & & \\
\hline EALER & $0.4915^{*}$ & $0.1298^{*}$ & -0.0364 & $0.1517 *$ & 1 & & & \\
\hline EPCM & $-0.1150 *$ & $-0.3370 *$ & $-0.2955^{*}$ & 0.0401 & 0.0174 & 1 & & \\
\hline $\mathrm{ECF}$ & $0.0633 *$ & 0.0234 & 0.0005 & 0.0639 & $-0.0754 *$ & -0.0018 & 1 & \\
\hline GDP & $-0.1273 *$ & -0.0272 & -0.0384 & -0.0683 & -0.0045 & 0.0149 & $0.0974 *$ & 1 \\
\hline
\end{tabular}

Note: Significance at $* \mathrm{p}<0.01$. Variable definitions are provided in Table 3. 


\section{Table 3. Summary of variable definitions and sources}

Table 2 defines the variables used in the paper and provides simple summary statistics. (1) The source of data used to estimate variables is Fitch IBCA's BankScope Database. (2) Data on the stock prices and indices were collected from DataStream database. (3) Data were collected from the Economic Freedom Index of the Heritage Foundation. (4) Data were collected from World Development Indicators of the World Bank.

\begin{tabular}{|c|c|c|c|c|}
\hline & Variable name & Mean & St. Dev. & Description \\
\hline \multirow[t]{4}{*}{ Risk measures ${ }^{(1,2)}$} & Capital-at-risk & 3.648 & 1.857 & CAR is a measure of investment banks' capital at risk. \\
\hline & Total revenues volatility & 0.225 & 0.229 & $\begin{array}{l}\text { бlnTR is a measure of rolling standard deviation of total revenues } \\
\text { over } 3 \text { years. }\end{array}$ \\
\hline & Return on assets volatility & 0.015 & 0.035 & $\begin{array}{l}\sigma \operatorname{lnROA} \text { is a measure of rolling standard deviation of ROA over } 3 \\
\text { years. }\end{array}$ \\
\hline & Market risk & 0.024 & 0.020 & MR is calculated as the standard deviation of stock returns. \\
\hline \multirow[t]{2}{*}{$\begin{array}{l}\text { Bank market structure and } \\
\text { competition }\end{array}$} & Efficiency-Adjusted Lerner index & 0.406 & 1.198 & $\begin{array}{l}\text { EALER is an indicator of the degree of market power derived } \\
\text { from a translog cost (and profit) function. }\end{array}$ \\
\hline & Excess price-cost margin & -0.059 & 1.338 & $\begin{array}{l}\text { EPCM is another proxy for market power, defined as the } \\
\text { difference between a bank's operating profit margin and the } \\
\text { average operating profit margin of its industry. }\end{array}$ \\
\hline Control variables ${ }^{(1)}$ & Bank type/specialization & & & $\begin{array}{l}\text { BT is a dummy variable, where the bank is full service or } \\
\text { specialised, where } 1=\text { FSIB; } 0=\text { BIB. }\end{array}$ \\
\hline Institutional environment ${ }^{(3)}$ & Economic freedom & 4.289 & 0.092 & $\begin{array}{l}\text { ECF is an indicator of economic freedom (ranging from } 0 \text { to } \\
100 \text { ). Greater values signify more freedom. It is in logarithm } \\
\text { form. }\end{array}$ \\
\hline Macroeconomic variables $^{(4)}$ & GDP growth & 0.9682 & 2.041 & GDP represents the growth in GDP (annual \%). \\
\hline
\end{tabular}


Table 4. Main results of the panel VAR model focusing on EALER (1997-2014)

\begin{tabular}{|c|c|c|c|c|}
\hline Variables & $\begin{array}{c}\text { 1) } \\
C A R\end{array}$ & $\begin{array}{c}\text { 2) } \\
\sigma \ln T R\end{array}$ & $\begin{array}{c}\text { 3) } \\
\sigma R O A\end{array}$ & $\begin{array}{c}\text { 4) } \\
M R\end{array}$ \\
\hline \multirow[t]{2}{*}{ RISK (t-1) } & $0.421 * * *$ & 0.138 & $0.549 * * *$ & $0.393 * * *$ \\
\hline & $(0.095)$ & $(0.218)$ & $(0.164)$ & $(0.102)$ \\
\hline \multirow[t]{2}{*}{ EALER (t-1) } & $-0.307^{*}$ & $-0.070^{*}$ & $0.003 * *$ & 0.000 \\
\hline & $(0.164)$ & $(0.040)$ & $(0.001)$ & $(0.005)$ \\
\hline \multirow[t]{2}{*}{$\mathrm{ECF}(\mathrm{t})$} & 0.098 & 0.719 & $0.221 * * *$ & 0.129 \\
\hline & $(2.771)$ & $(0.753)$ & $(0.076)$ & $(0.110)$ \\
\hline \multirow[t]{3}{*}{$\mathrm{GDP}(\mathrm{t})$} & $-0.331 * * *$ & 0.020 & 0.002 & 0.002 \\
\hline & $(0.096)$ & $(0.021)$ & $(0.002)$ & $(0.001)$ \\
\hline & EALER & EALER & EALER & EALER \\
\hline \multirow[t]{2}{*}{ RISK (t-1) } & 0.005 & -0.025 & 0.491 & -3.808 \\
\hline & $(0.036)$ & $(0.300)$ & $(1.051)$ & (3.153) \\
\hline \multirow[t]{2}{*}{ EALER (t-1) } & $0.952 * * *$ & $0.773 * * *$ & $0.859 * * *$ & $0.839 * * *$ \\
\hline & $(0.122)$ & $(0.112)$ & $(0.118)$ & $(0.314)$ \\
\hline \multirow[t]{2}{*}{$\mathrm{ECF}(\mathrm{t})$} & -1.181 & $-2.098 * *$ & $-2.215^{*}$ & 4.059 \\
\hline & $(0.977)$ & $(0.970)$ & (1.182) & (5.217) \\
\hline \multirow[t]{2}{*}{ GDP(t) } & $-0.147 * * *$ & $-0.077 * * *$ & $-0.120 * * *$ & -0.039 \\
\hline & $(0.038)$ & $(0.026)$ & $(0.031)$ & $(0.058)$ \\
\hline Hansen's J p-value & 0.271 & 0.669 & 0.756 & 0.322 \\
\hline Obs & 1514 & 1341 & 1346 & 340 \\
\hline
\end{tabular}

Note: Risk is alternatively CAR (for column 1), $\sigma \operatorname{lnTR}$ (for column 2), $\sigma$ ROA (for column 3 ) and MR (for column 4). Robust standard errors in brackets. Significance at $* * * \mathrm{p}<0.01, * * \mathrm{p}<0.05, * \mathrm{p}<0.1$. Variable definitions are provided in Table 2. 
Table 5. Main results of the panel VAR model focusing on EPCM (1997-2014)

\begin{tabular}{|c|c|c|c|c|}
\hline Variables & $\begin{array}{c}\text { 1) } \\
C A R\end{array}$ & $\begin{array}{c}\text { 2) } \\
\sigma \ln T R\end{array}$ & $\begin{array}{c}\text { 3) } \\
\sigma R O A\end{array}$ & $\begin{array}{c}\text { 4) } \\
M R\end{array}$ \\
\hline \multirow[t]{2}{*}{ RISK (t-1) } & $0.421 * * *$ & $0.180 * * *$ & 0.163 & $0.496 * * *$ \\
\hline & $(0.095)$ & $(0.059)$ & $(0.223)$ & $(0.156)$ \\
\hline \multirow[t]{2}{*}{ EPCM (t-1) } & $-0.307^{*}$ & $-0.073 * *$ & 0.005 & $0.004 * *$ \\
\hline & $(0.164)$ & $(0.032)$ & $(0.006)$ & $(0.002)$ \\
\hline \multirow[t]{2}{*}{$\mathrm{ECF}(\mathrm{t})$} & 0.098 & 0.509 & $0.406 * * *$ & -0.048 \\
\hline & $(2.771)$ & $(0.681)$ & $(0.120)$ & $(0.075)$ \\
\hline \multirow[t]{3}{*}{ GDP(t) } & $-0.331 * * *$ & 0.007 & $0.005 * *$ & 0.001 \\
\hline & $(0.096)$ & $(0.021)$ & $(0.002)$ & $(0.002)$ \\
\hline & EPCM & EPCM & EPCM & EPCM \\
\hline \multirow[t]{2}{*}{ RISK (t-1) } & -0.028 & 0.032 & -4.031 & -1.409 \\
\hline & $(0.021)$ & $(0.082)$ & (3.223) & (3.010) \\
\hline \multirow[t]{2}{*}{ EPCM (t-1) } & $0.281 * * *$ & $0.244 * * *$ & 0.153 & -0.021 \\
\hline & $(0.072)$ & $(0.065)$ & (0.108) & $(0.038)$ \\
\hline \multirow[t]{2}{*}{$\mathrm{ECF}(\mathrm{t})$} & -0.281 & $-5.946 * * *$ & $-9.030 * * *$ & -1.095 \\
\hline & $(0.730)$ & $(1.549)$ & (2.710) & (1.447) \\
\hline \multirow[t]{2}{*}{ GDP(t) } & -0.010 & $-0.136 * * *$ & $-0.120 * * *$ & -0.016 \\
\hline & $(0.024)$ & $(0.035)$ & $(0.044)$ & $(0.030)$ \\
\hline Hansen's J p-value & 0.164 & 0.570 & 0.219 & 0.518 \\
\hline Obs & 1591 & 1341 & 1346 & 340 \\
\hline
\end{tabular}

Note: Risk is alternatively CAR (for column 1), $\sigma \operatorname{lnTR}$ (for column 2), $\sigma \mathrm{ROA}$ (for column 3 ) and MR (for column 4). Robust standard errors in brackets. Significance at $* * * \mathrm{p}<0.01, * * \mathrm{p}<0.05$, $* \mathrm{p}<0.1$. Variable definitions are provided in Table 2. 
Table 6. Main results of the panel VAR model focusing on EALER (1997-2006)

\begin{tabular}{|c|c|c|c|c|}
\hline Variables & $\begin{array}{c}\text { 1) } \\
C A R\end{array}$ & $\begin{array}{c}\text { 2) } \\
\sigma \ln T R\end{array}$ & $\begin{array}{c}\text { 3) } \\
\sigma R O A\end{array}$ & $\begin{array}{c}\text { 4) } \\
M R\end{array}$ \\
\hline \multirow[t]{2}{*}{ RISK (t-1) } & $0.874 * * *$ & $0.573 * * *$ & $0.515 * * *$ & $0.698 * * *$ \\
\hline & $(0.130)$ & $(0.139)$ & $(0.159)$ & $(0.155)$ \\
\hline \multirow[t]{2}{*}{ EALER (t-1) } & $-0.474 *$ & 0.011 & $0.006 * *$ & -0.022 \\
\hline & $(0.245)$ & $(0.068)$ & $(0.003)$ & $(0.014)$ \\
\hline \multirow[t]{2}{*}{$\mathrm{ECF}(\mathrm{t})$} & 2.086 & 0.469 & $0.092 * *$ & -0.139 \\
\hline & $(1.596)$ & $(0.451)$ & $(0.041)$ & $(0.112)$ \\
\hline \multirow[t]{3}{*}{$\operatorname{GDP}(\mathrm{t})$} & $-0.306 * * *$ & 0.008 & -0.000 & 0.002 \\
\hline & $(0.067)$ & $(0.008)$ & $(0.001)$ & $(0.002)$ \\
\hline & EALER & $E A L E R$ & EALER & EALER \\
\hline \multirow[t]{2}{*}{ RISK (t-1) } & $0.149 * *$ & -0.081 & -0.011 & 7.444 \\
\hline & $(0.062)$ & $(0.111)$ & $(2.763)$ & $(4.595)$ \\
\hline \multirow[t]{2}{*}{ EALER (t-1) } & $0.959 * * *$ & $0.868 * * *$ & $0.821 * * *$ & 1.258 \\
\hline & $(0.133)$ & $(0.181)$ & $(0.194)$ & $(0.838)$ \\
\hline \multirow[t]{2}{*}{$\mathrm{ECF}(\mathrm{t})$} & 0.229 & $-1.218 *$ & $-2.324 * * *$ & 1.431 \\
\hline & $(0.795)$ & $(0.661)$ & $(0.800)$ & $(6.599)$ \\
\hline \multirow[t]{2}{*}{$\operatorname{GDP}(\mathrm{t})$} & $-0.047 *$ & -0.007 & 0.010 & 0.043 \\
\hline & $(0.028)$ & $(0.015)$ & $(0.020)$ & $(0.107)$ \\
\hline Hansen's J p-value & 0.122 & 0.780 & 0.720 & 0.865 \\
\hline Obs & 665 & 530 & 534 & 158 \\
\hline
\end{tabular}

Note: Risk is alternatively CAR (for column 1), $\sigma \operatorname{lnTR}$ (for column 2), $\sigma \mathrm{ROA}$ (for column 3 ) and MR (for column 4). Robust standard errors in brackets. Significance at $* * * \mathrm{p}<0.01, * * \mathrm{p}<0.05$, $* \mathrm{p}<0.1$. Variable definitions are provided in Table 2. 
Table 7. Main results of the panel VAR model focusing on EPCM (1997-2006)

\begin{tabular}{|c|c|c|c|c|}
\hline Variables & $\begin{array}{c}\text { 1) } \\
C A R\end{array}$ & $\begin{array}{c}\text { 2) } \\
\sigma \ln T R\end{array}$ & $\begin{array}{c}\text { 3) } \\
\sigma R O A\end{array}$ & $\begin{array}{c}\text { 4) } \\
M R\end{array}$ \\
\hline \multirow[t]{2}{*}{ RISK (t-1) } & $0.986 * * *$ & $0.596 * * *$ & $0.462 * * *$ & $0.748 * * *$ \\
\hline & $(0.200)$ & $(0.086)$ & $(0.162)$ & $(0.158)$ \\
\hline \multirow[t]{2}{*}{ EPCM (t-1) } & $-0.476^{*}$ & $-0.054 *$ & 0.003 & 0.000 \\
\hline & $(0.259)$ & $(0.031)$ & $(0.008)$ & $(0.000)$ \\
\hline \multirow[t]{2}{*}{$\mathrm{ECF}(\mathrm{t})$} & -0.515 & 0.292 & $0.112 * *$ & -0.015 \\
\hline & $(2.775)$ & $(0.453)$ & $(0.052)$ & $(0.048)$ \\
\hline \multirow[t]{3}{*}{$\operatorname{GDP}(\mathrm{t})$} & $0.088 * *$ & 0.010 & 0.001 & -0.002 \\
\hline & $(0.039)$ & $(0.008)$ & $(0.001)$ & $(0.001)$ \\
\hline & EPCM & EPCM & EPCM & EPCM \\
\hline \multirow[t]{2}{*}{ RISK (t-1) } & $-0.416 * * *$ & $-0.158 *$ & $-5.886 * * *$ & 0.686 \\
\hline & $(0.158)$ & $(0.085)$ & $(1.811)$ & $(2.638)$ \\
\hline \multirow[t]{2}{*}{ EPCM (t-1) } & $0.480 * *$ & $0.209 * * *$ & $0.631 * * *$ & $0.017 * * *$ \\
\hline & $(0.199)$ & $(0.058)$ & $(0.220)$ & $(0.000)$ \\
\hline \multirow[t]{2}{*}{$\mathrm{ECF}(\mathrm{t})$} & $-5.101 * *$ & $-2.508 * *$ & -1.022 & -0.318 \\
\hline & $(2.117)$ & $(1.135)$ & $(1.228)$ & $(0.812)$ \\
\hline \multirow[t]{2}{*}{$\operatorname{GDP}(\mathrm{t})$} & $-0.145^{* * *}$ & $-0.117 * * *$ & $-0.122 * * *$ & 0.025 \\
\hline & $(0.024)$ & $(0.019)$ & $(0.022)$ & $(0.016)$ \\
\hline Hansen's J p-value & 0.746 & 0.165 & 0.941 & 0.729 \\
\hline Obs & 748 & 530 & 534 & 158 \\
\hline
\end{tabular}

Note: Risk is alternatively CAR (for column 1), бlnTR (for column 2), $\sigma$ ROA (for column 3) and MR (for column 4). Robust standard errors in brackets. Significance at $* * * \mathrm{p}<0.01, * * \mathrm{p}<0.05, * \mathrm{p}<0.1$. Variable definitions are provided in Table 2. 
Table 8. Forecast Error Variance Decomposition

(8a): RISK measures are the impulse variables

\begin{tabular}{lccccc}
\hline & $\boldsymbol{Y e a r}$ & $\boldsymbol{C A R}$ & $\boldsymbol{\sigma l n T R}$ & $\boldsymbol{\sigma} \boldsymbol{R O A}$ & $\boldsymbol{M R}$ \\
\hline EALER & $\mathbf{1}$ & $13 \%$ & $3 \%$ & $2 \%$ & $1 \%$ \\
& $\mathbf{2}$ & $13 \%$ & $5 \%$ & $2 \%$ & $1 \%$ \\
& $\mathbf{3}$ & $13 \%$ & $5 \%$ & $2 \%$ & $1 \%$ \\
\hline EPCM & $\mathbf{1}$ & $0 \%$ & $13 \%$ & $28 \%$ & $9 \%$ \\
& $\mathbf{2}$ & $2 \%$ & $12 \%$ & $34 \%$ & $10 \%$ \\
& $\mathbf{3}$ & $2 \%$ & $12 \%$ & $34 \%$ & $10 \%$
\end{tabular}

(8b): EALER and EPCM are the impulse variables

\begin{tabular}{lccccc}
\hline & Year & $\boldsymbol{C A R}$ & $\boldsymbol{\sigma l n} \boldsymbol{T} \boldsymbol{R}$ & $\boldsymbol{\sigma} \boldsymbol{R O A}$ & $\boldsymbol{M R}$ \\
\hline EALER & $\mathbf{1}$ & $0 \%$ & $0 \%$ & $0.0 \%$ & $0 \%$ \\
& $\mathbf{2}$ & $1 \%$ & $0 \%$ & $0.4 \%$ & $0 \%$ \\
& $\mathbf{3}$ & $4 \%$ & $0 \%$ & $1 \%$ & $0 \%$ \\
\hline EPCM & $\mathbf{1}$ & $0 \%$ & $0 \%$ & $0 \%$ & $0.0 \%$ \\
& $\mathbf{2}$ & $0 \%$ & $0.3 \%$ & $1 \%$ & $0.3 \%$ \\
& $\mathbf{3}$ & $0 \%$ & $0.4 \%$ & $1 \%$ & $0.4 \%$ \\
\hline
\end{tabular}

Note: 1000 Monte Carlo Draws. 
Table 9. Main results of the panel VAR model with EALER calculated with Fourierflexible function $(1997-2014)$

\begin{tabular}{|c|c|c|c|c|}
\hline Variables & $\begin{array}{c}\text { 1) } \\
C A R\end{array}$ & $\begin{array}{c}\text { 2) } \\
\sigma \ln T R\end{array}$ & $\begin{array}{c}\text { 3) } \\
\sigma R O A\end{array}$ & $\begin{array}{c}\text { 4) } \\
M R\end{array}$ \\
\hline RISK (t-1) & $\begin{array}{c}0.387 * * * \\
(0.098)\end{array}$ & $\begin{array}{c}0.099 \\
(0.217)\end{array}$ & $\begin{array}{c}0.601 * * * \\
(0.160)\end{array}$ & $\begin{array}{c}0.382 * * * \\
(0.099)\end{array}$ \\
\hline EALER (t-1) & $\begin{array}{l}-0.216^{*} \\
(0.117)\end{array}$ & $\begin{array}{l}-0.051^{*} \\
(0.029)\end{array}$ & $\begin{array}{c}0.002 * * \\
(0.001)\end{array}$ & $\begin{array}{c}0.000 \\
(0.003)\end{array}$ \\
\hline $\mathrm{ECF}(\mathrm{t})$ & $\begin{array}{l}-0.049 \\
(2.787)\end{array}$ & $\begin{array}{c}0.999 \\
(0.753)\end{array}$ & $\begin{array}{c}0.215^{* * *} \\
(0.073)\end{array}$ & $\begin{array}{c}0.114 \\
(0.098)\end{array}$ \\
\hline GDP(t) & $\begin{array}{c}-0.325^{* * *} \\
(0.094)\end{array}$ & $\begin{array}{c}0.014 \\
(0.019)\end{array}$ & $\begin{array}{c}0.002 \\
(0.002)\end{array}$ & $\begin{array}{c}0.002 \\
(0.001)\end{array}$ \\
\hline & EALER & EALER & EALER & EALER \\
\hline RISK (t-1) & $\begin{array}{c}0.050 \\
(0.053)\end{array}$ & $\begin{array}{c}0.176 \\
(0.382)\end{array}$ & $\begin{array}{c}-1.066^{* * *} \\
(0.480)\end{array}$ & $\begin{array}{c}0.014 \\
(3.900)\end{array}$ \\
\hline EALER (t-1) & $\begin{array}{c}0.937 * * * \\
(0.127)\end{array}$ & $\begin{array}{c}0.740 * * * \\
(0.112)\end{array}$ & $\begin{array}{c}0.841 * * * \\
(0.096)\end{array}$ & $\begin{array}{c}0.728 * * \\
(0.286)\end{array}$ \\
\hline $\mathrm{ECF}(\mathrm{t})$ & $\begin{array}{l}-0.913 \\
(1.262)\end{array}$ & $\begin{array}{l}-1.239 \\
(1.303)\end{array}$ & $\begin{array}{l}-1.263 \\
(1.285)\end{array}$ & $\begin{array}{c}0.155 \\
(5.646)\end{array}$ \\
\hline GDP(t) & $\begin{array}{c}-0.160 * * * \\
(0.046)\end{array}$ & $\begin{array}{l}-0.055 \\
(0.034)\end{array}$ & $\begin{array}{c}-0.080 * * \\
(0.035)\end{array}$ & $\begin{array}{l}-0.075 \\
(0.075)\end{array}$ \\
\hline Hansen's J p-value & 0.341 & 0.941 & 0.377 & 0.132 \\
\hline Obs & 1514 & 1341 & 1346 & 340 \\
\hline
\end{tabular}

Note: Risk is alternatively CAR (for column 1), $\sigma \operatorname{lnTR}$ (for column 2), $\sigma \mathrm{ROA}$ (for column 3) and MR (for column 4). Robust standard errors in brackets. Significance at $* * * \mathrm{p}<0.01, * * \mathrm{p}<0.05,{ }^{*} \mathrm{p}<0.1$. Variable definitions are provided in Table 2. 
Table 10. Main model with the Boone Indicator $^{11}$

\begin{tabular}{lcccc}
\hline Variables & $\mathbf{1}$ & $\mathbf{2}$ & $\mathbf{3})$ & $\mathbf{4}$ \\
& $\boldsymbol{C A} \boldsymbol{R}$ & $\boldsymbol{\sigma l n} \boldsymbol{T} \boldsymbol{R}$ & $\boldsymbol{\sigma} \boldsymbol{R} \boldsymbol{A}$ & $\boldsymbol{M R}$ \\
\hline RISK (t-1) & $0.361^{* *}$ & 0.220 & -0.029 & $0.295^{* *}$ \\
& $(0.171)$ & $(0.222)$ & $(0.336)$ & $(0.138)$ \\
EALER (t-1) & $-9.002^{* *}$ & 0.269 & $0.396^{* * *}$ & -0.009 \\
& $(4.075)$ & $(0.645)$ & $(0.148)$ & $(0.022)$ \\
ECF(t) & $-13.019^{* * *}$ & 0.736 & $0.545^{* *}$ & $0.101^{*}$ \\
& $(5.010)$ & $(1.179)$ & $(0.218)$ & $(0.059)$ \\
GDP(t) & $-0.393^{* *}$ & -0.002 & -0.003 & 0.002 \\
& $(0.185)$ & $(0.021)$ & $(0.004)$ & $(0.002)$ \\
\hline Hansen's J p-value & 0.323 & 0.604 & 0.537 & 0.786 \\
Obs & 1514 & 1341 & 1346 & 340 \\
\hline
\end{tabular}

Note: Risk is alternatively CAR (for column 1), $\sigma \operatorname{lnTR}$ (for column 2), $\sigma \mathrm{ROA}$ (for column 3 ) and MR (for column 4). Robust standard errors in brackets. Significance at $* * * \mathrm{p}<0.01, * * \mathrm{p}<0.05$, $* \mathrm{p}<0.1$. Variable definitions are provided in Table 2.

${ }^{11}$ Mean and standard deviation of the Boone indicator are respectively -0.033 and 0.095 . 
Figure 1. Impulse-responses of the banks' risk measures to competition shock (EALER)

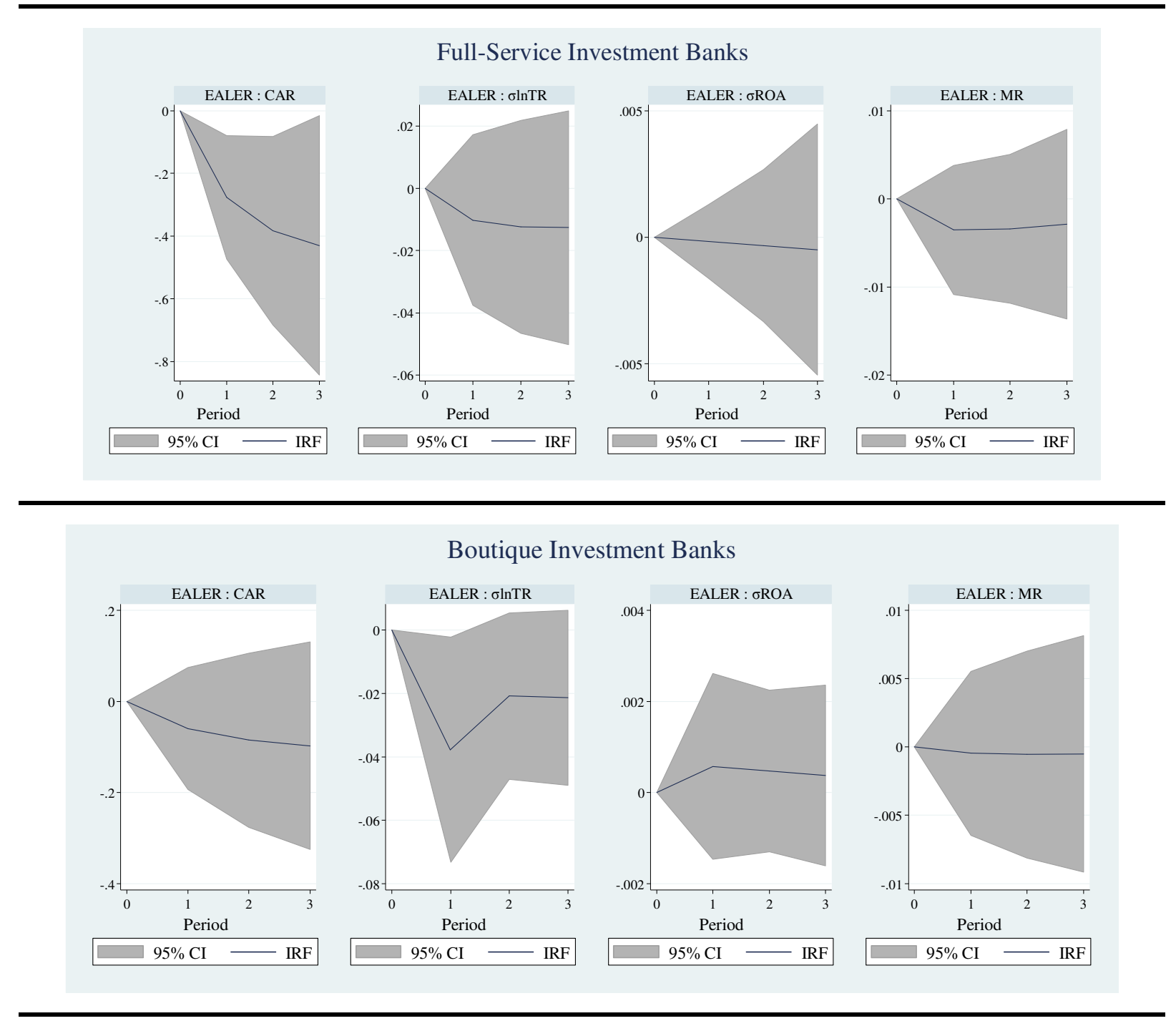

Note: Orthogonalized Impulse Response Functions (IRF). 95\% Confidence Interval (CI) generated by Monte-Carlo with 1000 reps. 
Figure 2. Impulse-responses of the banks' risk measures to competition shock (EPCM)

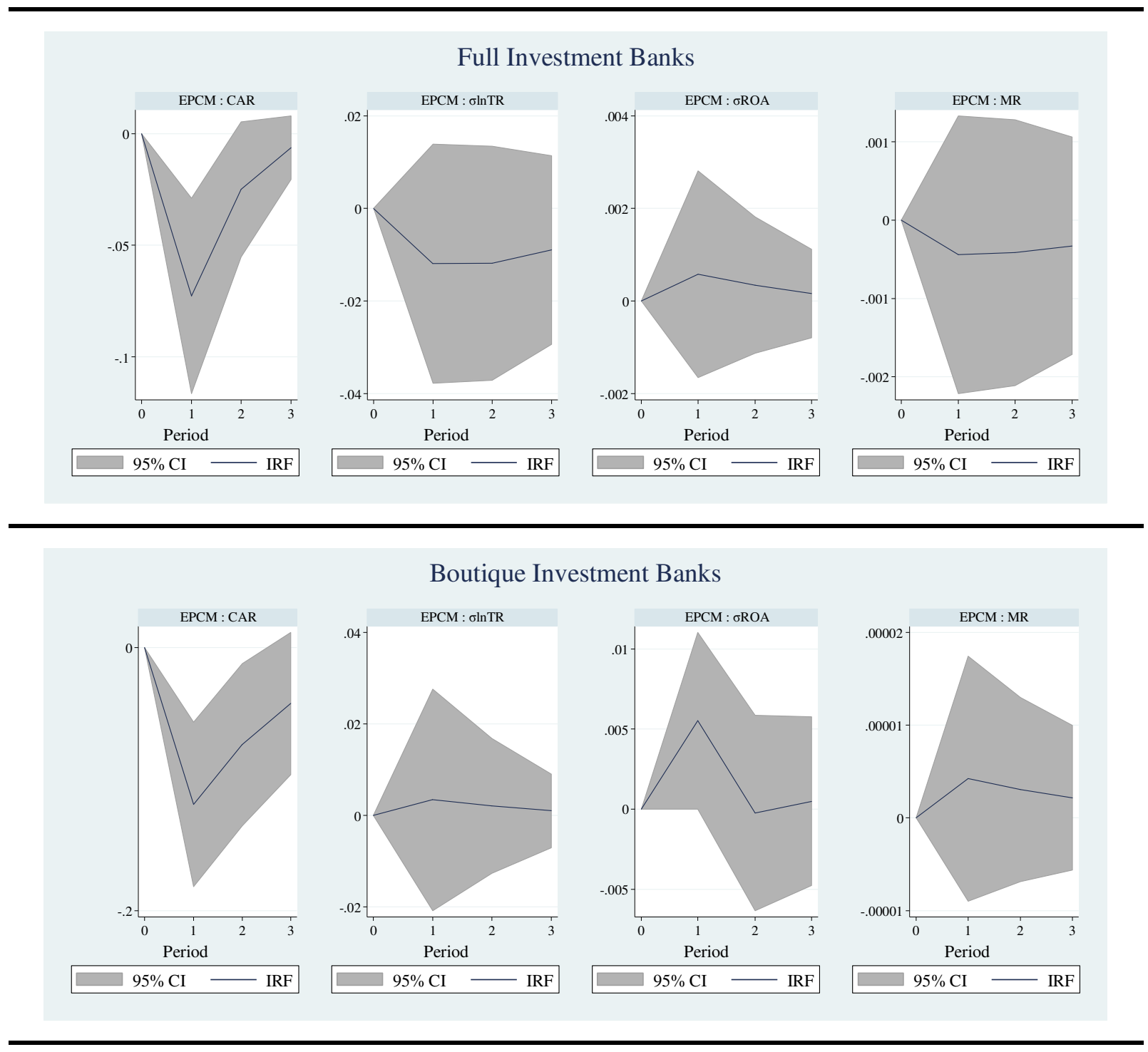

Note: Orthogonalized Impulse Response Functions (IRF). 95\% Confidence Interval (CI) generated by Monte-Carlo with 1000 reps. 